\title{
УДК 621.3+353.9
}

\section{METHODICAL APPROACHES IN RELATION TO EVALUATION OF EFFICIENCY OF PUBLIC MANAGEMENT AT GRANT OF SERVICES OF PUBLIC IN UKRAINE МЕТОДИЧНІ ПІДХОДИ ЩОДО ОЦІНЮВАННЯ ЕФЕКТИВНОСТІ ПУБЛІЧНОГО УПРАВЛІННЯ ПРИ НАДАННЯ ПОСЛУГ ГРОМАДСЬКОСТІ В УКРАЇНI}

Orlov N. / Орлов М. М. Doctor of Sciences in Public Administration, Associate Professor / Доктор наук з державного управління, доиент Kharkiv national university of building and architecture st. Symska, 40, 61002 Харківського національного університету будівництва та архітектури, вул.. Сумська 40, 61002.

Анотація. На основі аналізу літератури та знань про оцінювання ефективності управління подані методичні підходи щодо оцінювання ефективності публічного управління при наданні послуг громадськості в Україні. Визначено мету очінювання ефективності публічного управління при наданні послуг громадськості в Україні та принциипи оизінки ефективності публічного управління, які є основою для очінювання зазначеного управління. Сформульовані напрями подальшого дослідження зазначеного питання.

Ключові слова: ефективність, публічне управління, надання послуг, принципи оцінювання ефективності публічного управління, абсолютна $i$ відносна ефективність управління.

Вступ. Оцінювання ефективності у сфері будь-якого управління (державного, військового або публічного) є складним питанням, яке потребує не лише певних теоретичних знань, умінь та навичок дослідника, a i принципової перевірки на практиці. Як правило, перевірку на практиці здійснюють фізичні і юридичні особи, яким в результаті публічного управління надається низка послуг.

Огляд літератури. Питаннями публічного управління опікалися такі учені як Ю. Сурмін, В. Бакуменко, А. Михненко, Ю. Ковбасюка, Трощинський [1], Н. Гавкалова [2], И. Мазур, В. Шапиро, Н. Гольдерроге [3]. Що стосується ефективності управління, то цю проблему розглядали такі учені як Й. Кхол [4], А. Тищенко, Н. Кизим, Я. Догадайло [5], М. Мельник [6] та ін.

Разом 3 тим, автору статті не відомі наукові праці щодо оцінювання ефективності публічного управління при надання послуг громадськості в Україні.

Виходячи 3 поданого вище на думку автора статті, розгляд деяких державницьких підходів щодо теми дослідження є актуальним питанням і може розглядатися як проблемне питання сьогодення для України.

Мета статті: На основі знань про складність проблеми оцінювання ефективності публічного управління розглянуті деякі підходи цього оцінювання у разі надання послуг громадськості в Україні.

Основний текст. Як відомо, ефективність - те, що дає (визначає) отриманий ефект. Ефективність - співвідношення між продуктом у вигляді 
наданих товарів (послуг) i ресурсами, використаними на їх створення. Досягається шляхом аналізу технологій i методів роботи в організації, співпрацею підрозділів (служб, відділів, відділень), засобами заохочення працівників (управлінців) до скорочення витрат робочого часу. Eфективність це результативність функціонування системи та процесу управління як взаємодії керованої і керуючої систем, тобто інтегрований результат взаємодії компонентів управління. Ефективність показує якою мірою керуючий орган реалізує цілі, досягає запланованих результатів. Ефективність - це цільова установа, пов'язана з пошуком та вибором відповідного варіанту за заданими критеріями і забезпечення його реалізації на основі різноманітних підходів, наприклад, за допомогою прийняття рішення. Eфективність - це співвідношення між досягнутими результатами і використаними (затраченими) ресурсами [7].

Разом 3 тим у праці [7] подано поняття публічне управління - пошук найкращого способу використання ресурсів задля досягнення пріоритетних цілей суспільного розвитку, спільно організований урядом, представницькою владою та громадянським суспільством.

Там же зазначено, що послуга (service) - будь-яка діяльність або благо, коли одна сторона може запропонувати іншій. Послуги - види діяльності, робіт, у процесі виконання яких не створюється новий матеріально-речовинний продукт, не змінюється якість уже наявного, створеного продукту; блага, що надаються не у вигляді речей, а у формі діяльності.

3 урахування зазначеного вище, у межах теми дослідження доцільно розглянути перш за усе питання щодо мети оцінювання ефективності публічного управління при наданні послуг громадськості в Україні та принципи оцінки ефективності зазначеного управління.

1. Мета оцінювання ефективності публічного управління (в подальшому управління) при наданні послуг громадськості в Україні.

По-перше, оцінка ефективності управління повинна показати, в якій ступені існуюча система управління і показники їі функціонування сприяють як найповнішому використанню потенційних можливосте організації (системи публічного управління), узгоджуються із законами управління і відповідають безперервно зростаючим вимогам до нього.

По-друге, оцінка ефективності управління допомагає виявити вплив рівня підготовленості посадових осіб органів управління (їх компетенції та компетентність) на ефективність вирішення завдань управління, кількісно оцінити переваги, які можуть бути отримані від змін в розташуванні кадрів управлінців, залученню управлінців на навчання, а також той збиток управлінню, який може мати місце в результаті втрат (людські втрати) в умовах сьогодення.

По-третє, оцінка ефективності управління дає можливість наперед, ще до проведення заходів щодо вдосконалення системи управління, структури i методів роботи органів управління, оцінювати i прогнозувати їх результативність, щоб додати їм цілеспрямований характер, а не вести методом проб з подальшим виправленням можливих помилок. Це особливо важливо при 
вирішенні проблеми автоматизації управління, яка вимагає значних витрат часу i засобів і важко піддається переробкам і виправленням, хоча в подальшому значно підвищує ефективність управління в системі надання послуг громадськості.

По-четверте, в результаті оцінки ефективності управління повинно бути розрахунковим шляхом визначений стан системи управління (ступінь зниження рівня функціонування в умовах сьогодення) після різних видів впливів навколишнього середовища, щоб завчасно виявити найуразливіші місця $i$ виробити заходи щодо відновленню порушеного управління.

По- $n$ 'яте, важливе значення при оцінці ефективності управління має порівняльна характеристика своєї системи управління і систем управління іншої сторони (наприклад, умовного конкурента - противника відкритості при наданні послуг громадськості) що дозволяє об'єктивніше оцінювати співвідношення їх сил і прогнозувати розвиток власних дій у сфері надання послуг громадськості, сприяє виявленню слабких місць і дослідженню способів захисту своєї системи і вплив на систем управління конкурента.

Оскільки для порівняльної оцінки ефективності своєї системи управління i систем управління конкурента потрібно враховувати рівні підготовки управлінців сторін, то повинні вживатися заходи для того, щоб знати особисті якості посадовців органів управління конкурента (компетенції i компетентність) з можливо більшою повнотою. Крім того необхідно врахувати знання організації і технічних можливостей власної системи управління, офіційних поглядів на проблему надання послуг громадськості, моральнопсихологічних якостей управлінського апарату.

Початкові дані і розрахунки за визначенням рівня підготовки управлінців (рівня компетенцій та компетентності), особливо на перших порах, носять наближений характер, стосуються тільки основних посадовців, проте вони повинні стати основою для збору і використання детальнішої інформації.

2. Принципи оцінки ефективності публічного управління. Найважливішим принципом оцінки ефективності управління $є$ принцип системного підходу, згідно якому система управління, по-перше, розглядається як ієрархічна структура від вищих ланок до нижчих i, по-друге, кожна складова - як сукупність фізично і інформаційно пов'язаних між собою органів управління, пунктів управління, каналів обміну інформацією, автоматизованих i спеціальних систем (при їх наявності). Властивості системи управління не $\epsilon$ проста сума властивостей вхідних в неї складових, вони є новою якістю.

При дослідженні питання оцінювання ефективності публічного управління при наданні послуг громадськості в Україні необхідно розрізняти абсолютну і відносну ефективність управління.

Під абсолютною ефективністю управління розуміється той внесок, який вносить система управління в досягнення кінцевої мети організації. Але кількісно уявити безпосередній вплив управління на хід i результат дій організації, як правило, не можливо. Сама система управління має справу із отриманням, переробкою і відправленням інформації.

Що стосується внеску управління в кінцевий результат організації, то тут 
неминуча велика невизначеність, оскільки цей внесок не завжди пропорційний витратам на управлінський апарат. Прогнозуючи хід і результат майбутніх дій організації, як правило, не можливо точно охарактеризувати числом частку в успіху, яку можна в чистому вигляді приписати управлінню.

Оскільки оцінка абсолютної ефективності управління - завдання 3 наукової точки зору дуже складне, слід говорити про оцінку відносної ефективності управління, під якою розуміється результат зіставлення кількісних показників, щуо дозволяють оцінити переваги $і$ недоліки одного варіанту системи управління стосовно іншого ї̈ варіанту.

Система управління може оцінюватися 3 різних сторін i за різними показниками: 1) за витратами часу на цикл управління [8]; 2) за трудовитратами посадовців на вирішення тих або інших завдань управління; 3) за співвідношенням між основними (фактично керівниками) $\mathrm{i}$ допоміжними (що забезпечують управління) посадовцями органів управління; 4) за співвідношенням між творчими і строго регламентованими (нетворчою) видами діяльності посадовців органів управління; 5) за ступенем оснащеності пунктів і інших складових частин системи управління засобами автоматизації управління [9]; 6) за показниками вартості, надійності, живучості, перешкодозахищеності системи управління.

При цьому завжди слід мати на увазі, що створення довершеної системи управління - не самоціль. Ефективним може бути лише те управління, яке найкращим чином сприяє реалізації потенційних можливостей підлеглих об’єктів управління при надання послуг громадськості.

Отже, очінка ефективності управління повинна включати аналіз $i$ розрахунок внутрішньої $i$ зовнішньої ефективності системи управління. При цьому: 1) показники внутрішньої ефективності дозволяють оцінювати i порівнювати між собою системи управління як інструменти управлінської діяльності; 2) показники зовнішньої ефективності певною мірою відображають вплив системи управління на кінцевий результат дій об'єктів управління при надання послуг громадськості.

Ефективність управління повинна оцінюватися по сукупності показників внутрішньої і зовнішньої ефективності при визначальній ролі останніх i розглядатися не тільки з погляду оцінки окремих сторін системи управління, по набору додаткових показників, що дозволяють оцінити, в якому ступені задовольняються вимоги, що висуваються до системи управління, наскільки дотримуються специфічні закони управління i як підготовлені кадри управлінців, але і з погляду загальної оцінки шляхом вибору, визначення i порівняння чисельних значень якого-небудь одного узагальненого показника.

Загальна і часткові оцінки в сукупності повинні забезпечити досягнення всієї мети оцінки ефективності управління у сфері надання послуг громадськості, включаючи подальше вдосконалення системи управління i ii функціонування. Наявність таких показників і відпрацювання методів їх визначення та подальшого узагальнення не тільки створює можливість оцінювати варіанти діючих систем управління, але і сприятиме виробленню вимог до новостворюваних, зокрема до автоматизованих, систем управління. 


\section{Заключення і висновки.}

Отже, в статті розглянуті методичні підходи щодо оцінювання ефективності публічного управління при надання послуг громадськості в Україні лише 3 позиції: 1) мета оцінювання ефективності публічного управління при наданні послуг громадськості в Україні; 2) Принципи оцінки ефективності публічного управління.

Для аналізу і оцінки системи управління важливо, щоб певним вимогам відповідали не тільки окремі, часткові критерії оцінки іiі ефективності (простота, явний фізичний сенс, можливість обчислення, чутливість до змін параметрів системи), але інтегральні $i$ загальний критерії. Тому вся система критеріїв ефективності повинна бути певним чином уніфікована.

Нарешті, розроблення наукового апарату для оцінки ефективності управління повинна базуватися на комплексному використанні всього арсеналу сучасних методів дослідження, включаючи праці досвідчених учених, спеціальні експерименти, математичне моделювання тощо. При цьому найбільше утруднення має пошук методів узагальнення безлічі окремих критеріїв, що мають різний фізичний сенс і різну розмірність, в інтегральні i загальний критерії. Це і може бути темою подальшого дослідження поданої у статті проблеми.

Література:

1. Енциклопедичний словник з державного управління: Словник. / уклад.: Ю. П. Сурмін, В. Д. Бакуменко, А. М. Михненко та ін.; за ред. Ю. В. Ковбасюка, В. П. Трощинського, Ю. П. Сурміна, 2010 р. [Електронний ресурс]. Режим доступу:

http://chtyvo.org.ua/authors/Surmin_Yurii/Entsyklopedychnyi_slovnyk_z_derzh avnoho_upravlinnia/.

2. Вступ до публічного адміністрування: навчальний посібник / За заг. редакцією Гавкалової Н. Л. - Х. : ХНСУ імені Семена. Кузнеца, 2016. - 382 с.

3. Мазур И. И. Корпоративный менеджмент [Текст]/И. И. Мазур, B. Д. Шапиро, Н. Г. Ольдеррогге и др. - М. : Высшая школа, 2003. - 1077 с.

4. Кхол Й. Эффективность управленческих решений: Пер. с ческ. [Текст] / Й. Кхол - М. : Прогресс, 1975. - 165 с.

5. Тищенко А. Н., Кизим Н. А., Догадайло Я. В. Экономическая результативность деятельности предприятий: Монография. - X. : ИД «ИНЖЭК», 2005. - 144 с.

6. Мельник М. В. Анализ и оценка систем управления на предприятиях / М. В. Мельник. - М. : Финансы и статистика, 2009. - 136 с.

7. Орлов М. М. Тлумачний словник фахівця з менеджменту, маркетингу та публічного адміністрування (матеріали підготовлені до видання). - Х. : ХНУБА, 2019. - 323 с.

8. Орлов, М. М. Можливості системи управління Національної гвардії України [Текст] / М. М. Орлов, О. Ю. Іохов // Тези доповіді на VII науковопрактичній конференції "Наукове забезпечення службово-бойової діяльності Національної гвардії України” 31 березня 2016 р. - Х. : Національна академія 
Національної гвардії України, 2016. - С. 24-26.

9. Orlov N. M. State going near a necessity and directions of the centralized planning of points for the tactical link of management of the national household troops of Ukraine. Научный журнал «Власть и общество» (История, теория, практика) 1(37) 2016. ISSN-1512-374 Х. - Грузия. г. Тбилиси. Грузинский техн. ун-т, 2016. - С. 28-39.

\section{References:}

1. Encyclopaedic dictionary from state administration: Dictionary. (2010)/Q. Cyrmin, V. Bakymenko, A. Misnenko and other; at red. Q. Kovbasyk, V. Trosincki, Q. Cyrmin. [Electronic resource]. Access mode: vlinnia/.

http://chtyvo.org.ua/authors/Surmin_Yurii/Entsyklopedychnyi_slovnyk_z_derzhavnoho_upra

2. Prelude of public administration: train / aid After заг. by the release of N. Gavkalova. (2016). - X. : XNEY to the name of Semen. Kyznes, .- 382 p.

3. I Mazyr is the Corporate management [Text] (2003) / I Mazyr, V. Shahiro, N. Olderroge and other - M. : Higher school. - 1077 p.

4. Q. Khol. Efficiency of administrative decisions : Trudged. with ческ. [Text] (1975) / . Q. Khol - M. : Progress. - $165 \mathrm{p}$.

5. A. Tishenko, A.Kizim of N., Dogadalo. Economic effectiveness of activity of enterprises (2005) : Monograph. - X. : IDES of "INGEK". - 144 p.

6. M. Miller. Analysis and estimation of control system on the enterprises (2009) /M Miller. M. : Finances and statistics. - $136 \mathrm{p}$.

7. N. Orlov. Is the Explanatory dictionary of specialist on a management, marketing and public administration (materials are prepared to edition) (2019). - X. : XNYBA. - 323 p.

8. N. Orlov. Possibilities of control system of the National household troops of Ukraine [Text] / M. Orlov, A. Ioxov (2016) // Theses of lecture on VII to the research and practice conference the "Scientific providing of official-battle activity of the National household troops of Ukraine" on March, 31 in 2016 - X. : the National academy of the National household troops of Ukraine, 2016. P. 24-26.

9. N.Orlov . State going near a necessity and directions of the centralized planning of points for the tactical link of management of the national household troops of Ukraine. Scientific magazine "Power and society" (History, theory, practice) 1 (37). ISSN - 1512-374 X. it is Georgia. Tbilisi. Georgian Tex. Yniv-t. - P. 28-39.

Abstract. On the basis of analysis of literature and knowledge about the evaluation of management efficiency methodical approaches are given in relation to the evaluation of efficiency of public management at the grant of services of public in Ukraine. Certainly sweep the evaluation of efficiency of public management at the grant of services of public in Ukraine and principles estimations of efficiency of public management, that are basis for the evaluation of the marked management. Directions of further research of the marked question are set forth.

Key words: efficiency, public management, grant of services, principles of evaluation of efficiency of public management, absolute and relative efficiency of management.

Стаття підготовлена в межах наукової програми «Удосконалення механізмів надання публічних послуг на місцевому рівні в Україні».

Стаття відправлена: 19.03.2019 г.

(C) Орлов М.M. 